\title{
ASSESSMENT OF ENVIRONMENTAL QUALITY OF TWO INDUSTRIAL CITIES IN NORTH-CENTRAL NIGERIA USING METAL POLLUTION INDICES
}

\author{
Stephen Oyedeji1, Chinedu N. Eze², Clement O. Ogunkunle³, Paul O. Fatoba ${ }^{4}$
}

1,2,3,4 Plant Ecology and Environmental Management Unit, Department of Plant Biology, University of Ilorin, llorin, 240003 Nigeria.

Email: ${ }^{1}$ oyedeji.s@unilorin.edu.ng

\section{Abstract}

The study assessed the environmental quality around industrial areas of Jos and Kaduna, north-central Nigeria using heavy metals concentration in waste water (effluent) and atmospheric dust. Effluent and moss samples collected in replicates from two industrial sites in Jos and Kaduna were analyzed for $\mathrm{Cd}, \mathrm{Cu}, \mathrm{Pb}, \mathrm{Zn}$ and $\mathrm{Cr}$ using Atomic Absorption Spectrophotometer (Buck Scientific - 210 VGP). The concentrations of heavy metals in the effluents varied with site and location. Heavy metals concentrations were highest at the point of drain $(0 \mathrm{~m})$ across the industrial sites. Heavy metals contaminations were observed in mosses across the sites, with NGL (Jos) recording the highest levels. The pollution load indices reflected depletion in environmental quality across the industrial sites.

Key words: contamination, deposition, environmental health, heavy metals, pollution index, waste water.

\section{INTRODUCTION}

The indiscriminate release of industrial effluents into the environment is on the rise, especially in developing countries where no strict sanctions is in place to check the ugly trend. Industrial wastes generated from multifarious production processes are known to cause undesirable effects in living organisms. Most large cities in developing countries like Nigeria are feeling the pinch of pollution from industrial effluents as tons of untreated or incompletely treated wastes end up yearly in lagoons, rivers and streams [1]. Also, emissions from production and power generating plants, likewise atmospheric deposition from busy traffic of loading and unloading vehicles contribute significantly to heavy metals levels in the immediate environment around industries [2]. Heavy metals pollution is a great environmental problem as these pollutants accumulate to produce toxic effects in living organisms. Unlike biodegradable organic pollutants, heavy metals have great stability in living tissues and are transported throughout the food chain leading to serious ecological and health problems. Humans are exposed to these metals in many ways through air, water, soil and most commonly agricultural crops [3]. The health effects of these metals have been known since ancient history [4]. More worrisomely, some relatively accessible metals like copper $(\mathrm{Cu})$, chromium $(\mathrm{Cr})$, cadmium $(\mathrm{Cd})$, lead $(\mathrm{Pb})$ and zinc $(\mathrm{Zn})$ had been reported to produce toxic effects beyond permissible concentrations [5]. Diminished intellectual capacity, gastrointestinal symptoms, coronary heart disease, variety of cancers, such as renal, skin, and bladder cancers, and even death have also been associated with chronic and/or acute exposures to heavy metals [4]. Growth retardation and associated physiological disorders from $\mathrm{Cd}, \mathrm{Cr}, \mathrm{Cu}, \mathrm{Ni}, \mathrm{Pb}$ and $\mathrm{Zn}$ contaminated soils and irrigation water was also reported for plants [6].

The presence of heavy metal pollutants has been considered as useful indicators of contamination in surface soil, sediment and dust environments [7]. The use of mosses to monitors atmospheric pollutants has been well documented in literature [8][9]. The suitability of moss plants to monitor atmospheric pollution is hinged on their large surface area-volume ratio and the nonselective ability to absorb these chemicals directly from wet or dry deposition [10]. Monitoring environmental standards around industrials sites is necessary to reduce the risk of exposure to heavy metal contaminations associated with waste generation and contamination around the sites. The aim of this study is to assess the environmental quality in the industrial cities of Jos and Kaduna, north-central Nigeria using heavy metals concentration in effluents and atmospheric dusts.

\section{MATERIALS AND METHODS}




\section{A. Study areas}

The study was carried out in the industrial areas of Jos, and Kaduna, north-central Nigeria. Jos, the capital city of Plateau state was established in 1915 to serve as a transportation camp for tin. The city is located between latitudes $08^{\circ} 30 \square$ to $10^{\circ} 10 \square \mathrm{N}$ and longitudes $08^{\circ} 20 \square$ to $09^{\circ} 30 \square \mathrm{E}$ and lies on a plateau that stretches approximately $104 \mathrm{~km}$ from north to south and $80 \mathrm{~km}$ from east to west, covering an area of about $9,400 \mathrm{~km}^{2}$ [11]. The city enjoys near temperate climate and a beautiful landscape that makes it investor's destination in Nigeria. With an estimated population of about $1,000,000$ [12], the city houses many industries with some notable ones being NASCO Group, Grand Cereal and Oil Mills, Jos International Breweries and Northern Nigeria Fibre Products.

Kaduna, the capital city of Kaduna state is located between $10^{\circ} 27 \square \mathrm{N}$ to $10^{\circ} 38 \square \mathrm{N}$ and $7^{\circ} 20 \square \mathrm{E}$ to $7^{\circ}$ $35 \square \mathrm{E}$. It is a fast developing city with an estimated population of about 2 million in 2015 [13]. The unprecedented rise in population is adduced to its proximity to the Federal Capital Territory, Abuja [14]. The population growth has led to increased environmental pollution from various human activities including agriculture, mining, deforestation, urbanization, construction and industrialization [13]. Kaduna city today, is home to major industries and factories like Nigerian Breweries, Northern Noodles Ltd. (Indomie), Nigerian National Petroleum Corporation, United Nigeria Textiles Plc, Peugeot Automobile, to mention a few.

\section{B. Sampling and analysis}

Sampling locations for the study were selected in late October 2013 (early dry season in north-central Nigeria) based on the availability of moss plant around the factory and the release of wastewater from the factory. Two production factories each were selected in Jos [NASCO Group Limited (NGL) and Grand Cereal and Oil Mill Limited (GCL)] and in Kaduna [Nigerian Breweries Plc. (NBP) and United Nigeria Textiles PIc. (UNP)]. Farin Gada (in Jos) and Angar Makama (in Kaduna), where moss plants were growing with less human interference were chosen as the Control sites. Green/brownish green moss plants reflecting recent seasonal growth were collected in five replicates from wood and sandcrete materials at points around the perimeter of the factory site. The collected moss samples were washed with deionized water to remove debris and air dried to a constant weight. Dried moss samples were homogenized in a stainless steel blender prior to chemical analysis. Effluent samples were collected in five replicates at $0 \mathrm{~m}$ (point of release/drain just outside the factory), $10 \mathrm{~m}$ and $20 \mathrm{~m}$ along each factory wastewater drain and acidified with nitric acid $\left(\mathrm{HNO}_{3}\right)$ prior to chemical analysis. $1 \mathrm{~g}$ of moss sample or $1 \mathrm{ml}$ of effluent sample was digested with 30 $\mathrm{ml}$ concentrated nitric acid $\left(\mathrm{HNO}_{3}\right)$ and $10 \mathrm{ml}$ hydrochloric acid $(\mathrm{HCl})$ was added sequentially. The mixture was heated on a hot plate until a clear solution was visible. The digest was filtered through Whatman filter paper No. 42 and made up to $100 \mathrm{ml}$ with deionized water. Concentrations of cadmium (Cd), copper $(\mathrm{Cu})$, lead $(\mathrm{Pb})$, zinc $(\mathrm{Zn})$ and chromium $(\mathrm{Cr})$ were determined from the filtrate using atomic absorption spectrophotometer (Buck Scientific Model 210 VGP) at wavelengths $(\lambda)$ of 228.8 $\mathrm{nm}$ for $\mathrm{Cd}, 324.7 \mathrm{~nm}$ for $\mathrm{Cu}, 283.3 \mathrm{~nm}$ for $\mathrm{Pb}, 213.8 \mathrm{~nm}$ for $\mathrm{Zn}$ and $357.9 \mathrm{~nm}$ for $\mathrm{Cr}$. Quality assurance for heavy metals in the moss plants were carried out using certified reference material (IAEA-336) while blanks were prepared for both moss and water samples.

Data obtained for metal concentrations in wastewater and moss plants were analyzed using SAS 9.3 for Windows. Data for heavy metals in the moss plants were used to determine the degree of contamination around the factory using the contamination factor $(C F)$, degree of contamination $\left(C_{d}\right)$, modified degree of contamination $\left(m C_{d}\right)$ and pollution load index $(P L l)$.

The contamination factor was calculated as

Contamination Factor, $C F=\frac{c_{m}}{c_{\text {background }}} \ldots .$. (1)

Where $C_{m}$ is the concentration of the metal in the moss sample around the factory and $C_{\text {background }}$ is the background concentration of the metal in the moss. The degree of contamination $\left(C_{d}\right)$ is calculated from (1) thus:

\section{Degree of Contamination, $C_{d}=\sum_{1=1}^{N} C F i \quad \ldots \ldots$.}

(2) 
Where $\mathrm{CF} i$ is the contamination factor for the $i^{\text {th }}$ metal and $\mathrm{N}$ is the number of metals considered. The modified degree of contamination $\left(m C_{d}\right)$ was obtained from (2) as

\section{Degree of Contamination, $m C_{d}=\frac{1}{N} \sum_{1=1}^{N} C F i$}

The pollution load index (PLI) was calculated from thus:

Pollution load index, $P L I=\left(C F_{1} \times C F_{2} \times C F_{3} \times \ldots \times C F_{N}\right)^{1 / N}$

The PLI gives an estimate of the metal contamination status and the necessary action that should be taken. A $P L I<1$ denote perfection; $P L I=1$ indicate that only baseline levels of pollutants are present and $P L I>1$ indicate deterioration of site quality [15].

The categories for contamination factor (CF) and degree of contamination $\left(C_{d}\right)$ are presented in Table 1 while the classes of modified contamination factor $\left(m C_{d}\right)$ according to Likuku et al. [16] are presented in Table 2.

\section{RESULTS AND DISCUSSION}

\section{A. Metal concentrations in industrial effluents}

The results for $\mathrm{Cd}, \mathrm{Cu}, \mathrm{Pb}, \mathrm{Zn}$ and $\mathrm{Cr}$ concentration in the effluents from NGL (Jos) are shown in Fig. 1. The concentrations of the studied metals were highest at $0 \mathrm{~m}$ from the factory. $\mathrm{Pb}$ and $\mathrm{Cr}$ had the highest and lowest concentrations respectively in the effluent in all three sampling points $(0,10$ and $20 \mathrm{~m}$ from the drain point). The results of heavy metals in effluents from GCL (Jos) showed $\mathrm{Cd}$ had the least concentration at the 3 sampling points (Fig 2). $\mathrm{Cr}$ concentration was highest at the $0 \mathrm{~m}$ point but lower than $\mathrm{Cu}$ at $10 \mathrm{~m}$ point. The concentrations of $\mathrm{Cr}, \mathrm{Cu}$ and $\mathrm{Pb}$ were highest in the effluent at $20 \mathrm{~m}$ $(2.69 \pm 0.32 \mathrm{mg} / \mathrm{l}, 2.51 \pm 0.40 \mathrm{mg} / \mathrm{l}$ and $2.69 \pm 0.70 \mathrm{mg} / \mathrm{l}$ respectively). The concentrations of the $\mathrm{Cd}, \mathrm{Cu}, \mathrm{Pb}$ and $\mathrm{Zn}$ in the effluents from NGL were higher than $0.38 \mathrm{mg} /$, $0.37 \mathrm{mg} / \mathrm{l}, 1.03 \mathrm{mg} / \mathrm{kg}$ and $1.87 \mathrm{mg} / /$ respectively reported in polluted river dam in Jos [17]. The results of $\mathrm{Cd}$ and $\mathrm{Zn}$ for GCL were within the range of $0.01-0.38 \mathrm{mg} / \mathrm{l}$ and $0.95-1.87 \mathrm{mg} / \mathrm{l}$ reported respectively for both metals in Jos. Figure 3 showed higher concentrations of all metals at $0 \mathrm{~m}$ than at $10 \mathrm{~m}$ and $20 \mathrm{~m}$ from the factory (NBP,
Kaduna). The order of metals concentration was $\mathrm{Cd}>\mathrm{Zn}$ $>\mathrm{Cu}>\mathrm{Cr}>\mathrm{Pb}$ at $0 \mathrm{~m}$ and $10 \mathrm{~m}$. However, $\mathrm{Zn}$ was higher than $\mathrm{Cd}$ at $20 \mathrm{~m}$. In waste water from UNP (Kaduna), $\mathrm{Cr}$ and $\mathrm{Cd}$ concentrations were highest. Metals concentration decreased with increasing distance from the drain point (Fig. 4). The concentrations of the metals in the effluents from GCL were low compared with most of the other sites. The levels of $\mathrm{Cd}, \mathrm{Cr}$ and $\mathrm{Cu}$ in the effluents across the sites were higher than the permissible limits of $0.01,0.10$ and $0.20 \mathrm{mg} / \mathrm{l}$ respectively stipulated by FAO for irrigation purposes [18]. The levels of $\mathrm{Zn}$ in most of the sampled points also exceeded 2.00 $\mathrm{mg} / \mathrm{l}$ permitted by FAO, except for the UNP at the $20 \mathrm{~m}$ point and GCL at both $10 \mathrm{~m}$ and $20 \mathrm{~m}$ points. $\mathrm{Pb}$ levels across the industrial sites were within $\mathrm{FAO}$ permissible limits of $5.00 \mathrm{mg} / \mathrm{l}$ except for NGL.

\section{B. Metal concentrations in mosses and environmental quality assessment}

The results of metal concentrations in the moss plants revealed significant differences among the metals and variations in various orders of magnitude from site to site (Table 3). $\mathrm{Pb}$ concentration was highest in NGL $(14.29 \pm 1.80 \mathrm{mg} / \mathrm{kg})$ while $\mathrm{Cr}$ had the least $(5.98 \pm 0.71$ $\mathrm{mg} / \mathrm{kg}$ ). Metal concentrations in mosses at NGL were higher than at GCL. The concentration of $\mathrm{Cu}$ was highest in NBP $(10.19 \pm 1.35 \mathrm{mg} / \mathrm{kg})$ while Cd was highest in UNP $(7.44 \pm 1.62 \mathrm{mg} / \mathrm{kg})$. Heavy metal contamination in moss plants gives a reflection of atmospheric quality as these plants are able to obtain elements and nutrients directly from wet and dry deposition [19]. Cd levels in the mosses around NGL and UNP were higher than reported for 1.54 $-2.54 \mathrm{mg} / \mathrm{kg}$ reported for Jos [20]. The level of $\mathrm{Cd}$ at NBP was within the cited range but it was much lower at $\mathrm{GCL}$. The levels of $\mathrm{Cu}, \mathrm{Pb}$ and $\mathrm{Zn}$ across all sites were lower than the reported ranges of $24.5-67.0 \mathrm{mg} / \mathrm{kg}, 25.0$ $66.0 \mathrm{mg} / \mathrm{kg}$ and $35.0-123 \mathrm{mg} / \mathrm{kg}$ respectively for the area [20]. Cr concentrations across the sites were higher than the reported range of $0.019-0.111 \mathrm{mg} / \mathrm{kg}$ for Jos [21].

The results of contamination factor $(C F)$ shows that NGL was very highly contaminated with $\mathrm{Pb}, \mathrm{Cu}$ and $\mathrm{Cd}$ but considerably contaminated with $\mathrm{Zn}$ and $\mathrm{Cr}$ (Table 4). GCL was low for $\mathrm{Cd}$ contamination, moderate for $\mathrm{Zn}$ and $\mathrm{Cu}$, but considerably high for $\mathrm{Cr}$ and $\mathrm{Pb}$. NBP was moderately contaminated with $\mathrm{Cd}$ but very highly contaminated with $\mathrm{Cr}, \mathrm{Zn}, \mathrm{Cu}$ and $\mathrm{Pb}$. UNP was however 
moderately contaminated by $\mathrm{Cu}$ and $\mathrm{Pb}$, considerably highly contaminated by $\mathrm{Zn}$ and very highly contaminated by $\mathrm{Cr}$ and $\mathrm{Cd}$. The assessment of the site quality using metal contamination factors in the mosses around industrial sites, relative to the less polluted control site, showed high contamination with heavy metals $\left(C_{d}>32\right)$, except for GCL. The very high contamination indicated for NGL and NBP by the $C_{d}$ index was further confirmed by the modified contamination factors $\left(m C_{d}\right)$ of 11.13 and 9.77 respectively. However, $m C_{d}$ index for NBP revealed high degree of contamination $\left(m C_{d}=6.72\right)$ while $\mathrm{GCL}$ $\left(m C_{d}=2.13\right)$ was confirmed to be moderately contaminated. The pollution load index for all the factory sites revealed deterioration of the site quality $(P L I>1)$. Except for the contamination factor for $\mathrm{Cd}$ in $\mathrm{GCL}, \mathrm{CF}$ and $P L /$ value were generally higher than the reported for Jos metropolitan [20].

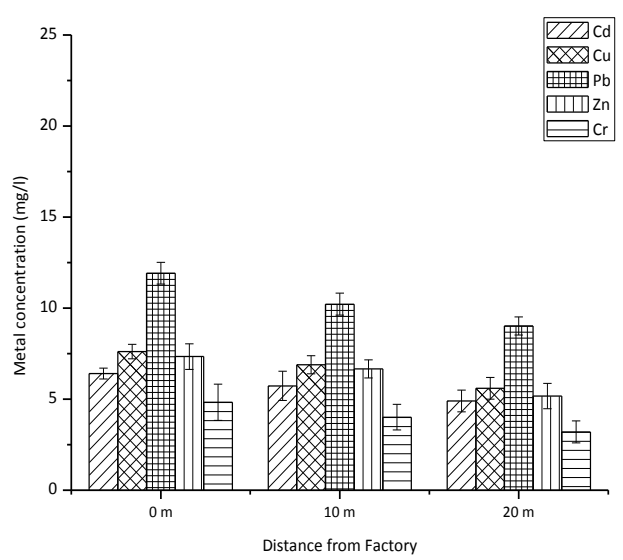

Fig. 1: Heavy metal concentrations in effluent from NGL (Jos).

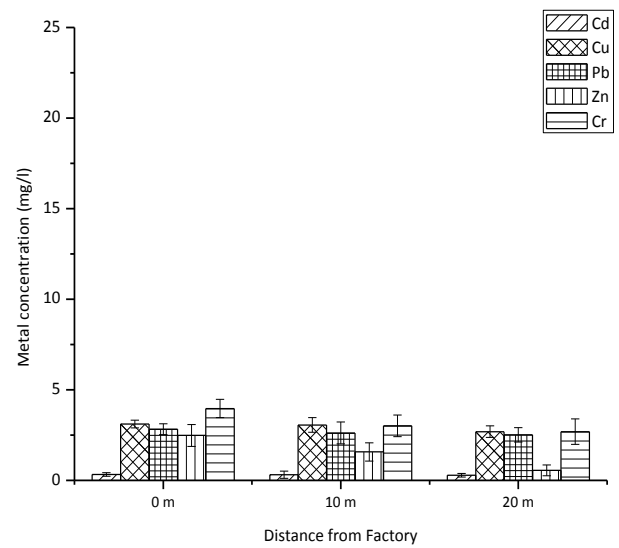

Fig. 2: Heavy metal concentrations in effluent from GCL (Jos).

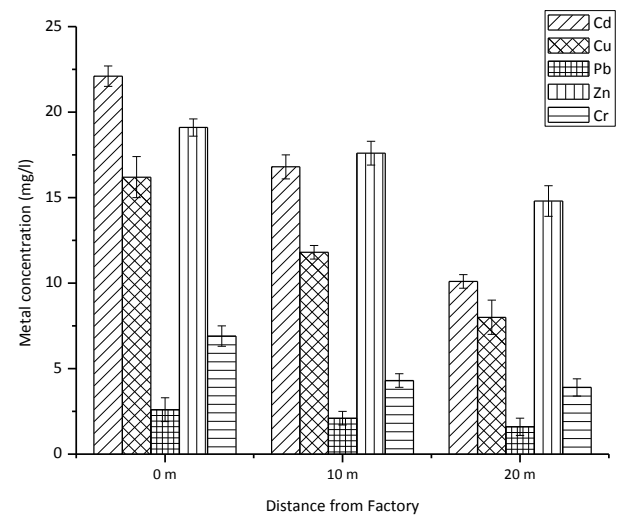

Fig. 3: Heavy metal concentrations in effluent from NBP (Kaduna).

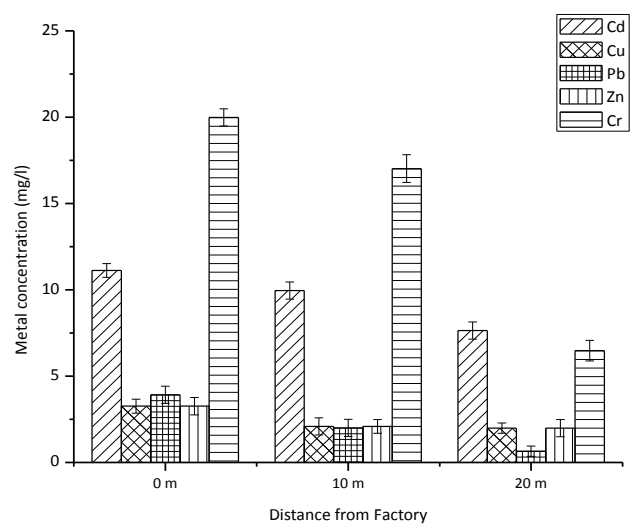

Fig. 4: Heavy metal concentrations in effluent from UNP (Kaduna).

Table 1: Contamination factors and degree of contamination categories and terminologies

\begin{tabular}{lll}
\hline$C F$ classes & $C F$ and $C_{d}$ terminologies & $C_{d}$ classes \\
\hline$C F<1$ & Low $C F /$ low $C_{d}$ & $C_{d}<8$ \\
$1 \leq C F<3$ & Moderate $C F / C_{d}$ & $8 \leq C_{d}<16$ \\
$3 \leq C F<6$ & Considerable $C F / C_{d}$ & $16 \leq C_{d}<32$ \\
$C F \geq 6$ & Very high $C F / C_{d}$ & $C_{d} \geq 32$ \\
\hline
\end{tabular}

Table 2: Modified degree of contamination classification and description

\begin{tabular}{ll}
\hline$m C_{d}$ classes & Modified degree of contamination level \\
\hline$m C_{d}<1.5$ & Nil to very low degree of contamination \\
$1.5 \leq m C_{d}<2$ & Low degree of contamination \\
$2 \leq m C_{d}<4$ & Moderate degree of contamination \\
$4 \leq m C_{d}<8$ & High degree of contamination \\
$8 \leq m C_{d}<16$ & Very high degree of contamination \\
$16 \leq m C_{d}<32$ & Extremely high degree of contamination \\
$m C_{d} \geq 32$ & Ultra high degree of contamination \\
\hline
\end{tabular}


Table 3: Heavy metals concentrations in mosses (in mg/kg) around industrial sites in Jos and Kaduna, Nigeria.

\begin{tabular}{|c|c|c|c|c|c|c|}
\hline \multirow{2}{*}{ Site } & \multicolumn{3}{|c|}{ Jos } & \multicolumn{3}{|c|}{ Kaduna } \\
\hline & NGL & GCL & Control & NBP & UNP & Control \\
\hline $\mathrm{Cd}$ & $13.34^{\mathrm{a} \pm 3.19}$ & $0.49 \mathrm{e} \pm 0.04$ & $1.02 \pm 0.30$ & $2.53^{\mathrm{e}} \pm 0.46$ & $7.44^{a} \pm 1.62$ & $0.90 \pm 0.30$ \\
\hline $\mathrm{Cu}$ & $13.35^{\mathrm{a}} \pm 2.34$ & $2.10^{c} \pm 0.49$ & $1.00 \pm 0.49$ & $10.19 \mathrm{a} \pm 1.35$ & $2.65^{c} \pm 1.00$ & $1.10 \pm 0.30$ \\
\hline $\mathrm{Pb}$ & $14.29 \mathrm{a} \pm 1.80$ & $2.91^{b} \pm 0.36$ & $0.80 \pm 0.20$ & $8.52^{b} \pm 0.70$ & $2.25^{c} \pm 0.61$ & $1.00 \pm 0.19$ \\
\hline $\mathrm{Zn}$ & $6.17^{b} \pm 3.15$ & $1.14^{\mathrm{d}} \pm 0.12$ & $1.07 \pm 0.30$ & $5.55^{c} \pm 1.45$ & $2.40^{c} \pm 0.57$ & $0.50 \pm 0.11$ \\
\hline $\mathrm{Cr}$ & $5.98^{b} \pm 0.71$ & $3.62^{\mathrm{a}} \pm 0.43$ & $1.00 \pm 0.20$ & $5.14^{d} \pm 0.82$ & $4.76^{b} \pm 2.54$ & $0.30 \pm 0.04$ \\
\hline
\end{tabular}

Values are mean \pm standard deviation. Means with the same superscripted letter are not significantly different at $\alpha=0.05$.

Table 4: Contamination factor, degree/modified degree of contamination and pollution index for heavy metals deposits on mosses around industrial sites in Jos and Kaduna.

\begin{tabular}{cccccc}
\hline & Metals & NGL & GCL & NBP & UNP \\
\hline \multirow{4}{*}{$\mathrm{CF}$} & $\mathrm{Cd}$ & 13.08 & 0.48 & 2.81 & 8.27 \\
& $\mathrm{Cu}$ & 13.35 & 2.10 & 9.26 & 2.41 \\
& $\mathrm{~Pb}$ & 17.86 & 3.64 & 8.52 & 2.25 \\
& $\mathrm{Zn}$ & 5.77 & 1.07 & 11.10 & 4.80 \\
& $\mathrm{Cr}$ & 5.59 & 3.38 & 17.13 & 15.87 \\
& & 55.65 & 10.67 & 48.83 & 33.59 \\
$C_{d}$ & & 11.13 & 2.13 & 9.77 & 6.72 \\
$m C_{d}$ & & 10.01 & 1.68 & 8.41 & 5.09 \\
\hline
\end{tabular}

\section{CONCLUSION}

The high concentrations of heavy metals in effluent at close distances to the factory confirm contamination from anthropogenic releases rather than soil weathered materials. The high pollution indices for metal contamination reflect deterioration of site quality from industrial waste releases. It is therefore recommended that industries should be cited remote for residential and agricultural lands as to prevent associated health risk from heavy metals contamination.

\section{ACKNOWLEDGEMENT}

The authors would like to thank5plant ecology and environmental management unit, department of plant biology, university of ilorin, ilorin, 240003 nigeria

\section{REFERENCES}

[1] Olaniyi, I., Raphael O. and Nwadiogbu, J. O. 2012. Effect of industrial effluent on the surrrounding environment. Archives of Applied Science Research, 4(1), pp. 406-413.

[2] Jankiewicz, B. and Adamczyk, D. 2010. Assessing heavy metal content in soils surrounding a power plant. Polish Journal of Environmental Studies, 19(4), pp. 849-853.

[3] Nriagu, J. O. 1996. History of global metal pollution. Science, 272, pp. 223-224.

[4] Maleki, A., Amini, H., Nazmara, S., Zandi, S. and Mahvi, A. H. 2014. Spatial distribution of heavy metals in soil, water, and vegetables of farms in Sanandaj, Kurdistan, Iran.
Journal of Environmental Health Science and Engineering, 12: 136.

[5] Wood, J. M. 1974. Biological cycles for toxic elements in the Maleki, A., Amini, H., Nazmara, S., Zandi, S. and Mahvi, A. H. 2014. [6]. Spatial distribution of heavy metals in soil, water, and vegetables of farms in Sanandaj, Kurdistan, Iran. Journal of Environmental Health Science and Engineering, 12: 136.

[6] Ubwa, S. T., Abah, J., Ada, C. A. and Alechenu, E. 2013. Levels of some heavy metals contamination of street dust in the industrial and high traffic density areas of Jos Metropolis", Journal of Biodiversity and Environmental Sciences, 3(7), pp. 13-21.

[7] Gerdol, R., Bragazza, L. and Marchesini, R. 2002. Element concentrations in the forest moss Hylocomium splendens: variation associated with altitude, net primary production and soil chemistry. Environmental Pollution, 16, pp. 129135.

[8] Fernandez, J. E., Ederra, A., Nunez, E., Martinez-Abaigar, J. Infante, M., Heras, P., Elias, M. J., Mazimpaka, V. and Carballiera, A. 2002. Biomonitoring of metal deposition in northern Spain by moss analysis. Science of the Total Environment, 300, pp. 115-127.

[9] Zechmeister, H., Hohenwallner, D., Riss, A. and HanusIllnar, A. 2003. Variation in metal concentrations in the moss species Abietinella abietina (Hedw) Fleisch. according to a sampling time, within site variability and increase in biomass. Science of the Total Environment, 301, pp. 55-65.

[10] Plateau State of Nigeria Gazette 2004. Plateau Resolves: Report of the Plateau Peace Conference, 2004, 18th August - 21st September, 2004 - Main Report (September, 2004). Government Printer, Jos.

[11] National Bureau of Statistics 2006. Federal Republic of Nigeria, 2006 Population Census. Available at web.archive.org/web/20120305101910/http://www.nigerian stat.gov.ng/nbsapps/Connections/Pop2006.pdf

[12] Saleh, Y., Badr, A. M., El Banna, F. and Shahata, A. 2014. Agricultural land-use change and disappearance of farmlands in Kaduna metropolis-Nigeria. Science World Journal, 9(1), pp. 1-7.

[13] Abbas, I. I., Adama, Y. A. and Ukoje, J. A. 2010. Street mapping using remotely sensed data and GIS technique. Research Journal of Applied Sciences, Engineering and Technology, 2(2), pp. 191-197. 
[14] Tomlinson, D. L., Wilson, J. G., Harris, C. R., Jeffrey, D. W. 1980. Problem in the assessment of heavy metals levels in estuaries and the formation of a pollution index. Helgoländer Meeresuntersuchungen, 33, pp. 566-575.

[15] Likuku, A. S., Mmolawa, K. B. and Gaboutloeloe, G. K. 2013. Assessment of heavy metal enrichment and degree of contamination around the copper-nickel mine in the Selebi Phikwe Region, Eastern Botswana. Environment and Ecology Research, 1(2), pp. 32-40.

[16] Sabo, A., Gani, A. M. and Ibrahim, A. Q. 2013. Pollution status of heavy metals in water and bottom sediment of River Delimi in Jos, Nigeria. American Journal of Environmental Protection, 1(3), pp. 47-53.

[17] Food and Agricultural Organization of the United Nation (FAO) 2015. Wastewater treatment and use in agriculture: Wastewater quality guidelines for agricultural use. Available from FAO repository at http://www.fao.org/docrep/t0551e/t0551e04.htm\#TopOfPag $\underline{\mathrm{e}}$
[18] Vasconcelos, M. T. and Tavares, H. M. 1993. The suitability of the mosses Sphagna as quantitative indicators of heavy metal levels in urban atmospheres. In: Travis, C. C. (ed.), Use of Biomarkers in Assessing Health and Environmental Impacts of Chemical Pollutants. Plenum Press, New York, pp. 67-71.

[19] Mafuyai, G. M., Kamoh, N. M., Kangpe, N. S. Ayuba, S. M., Eneji, I. S. 2015. Heavy metals contamination in roadside dust along major traffic roads in Jos Metropolitan area, Nigeria. Journal of Environment and Earth Science, 5(5), pp. 48-57.

[20] Mafuyai, G. M., Eneji, I. S., and Sha'Ato, R. 2014. Concentration of heavy metals in respirable dust in Jos Metropolitan Area, Nigeria. Open Journal of Air Pollution, 3 , pp. 10-19. 